\title{
Folyamatosan öntött acélok gyártási körülményeinek hatása a melegen hengerelt termék leminősülésének mértékére
}

\section{Effect of the production conditions of continuously cast steels on the degree of hot rolled product downgrading}

\author{
Wizner Krisztián, ${ }^{1}$ Kővári Attila ${ }^{2}$ \\ ${ }^{1}$ ISD Dunaferr Zrt., Dunaújváros, Magyarország, wizner.krisztian@isd-dunaferr.hu \\ ${ }^{2}$ Dunaújvárosi Egyetem, Müszaki Intézet, Dunaújváros, Magyarország, kovari@uniduna.hu
}

\begin{abstract}
Nowadays, quality development is a growing challenge, which places a heavy burden on economic operators, especially on smaller companies. ISD Dunaferr Zrt is the largest steel company in Hungary with its annual steel production of about 2 million tons, but it is small on a global scale. Taking advantage of the opportunities, locating the hidden problems, qualitative development and productivity enhancement can be realized without major investment. This study points out the steel production and casting parameters that have the greatest impact on the quality of the hot rolled product (sheet and coil) and touches upon the effect of rolled product final thickness on the ratio of downgrading. As a result the examination of overheating shows correlation with the ratio of downgrading, but the age of the mould does not. Regarding the thickness of the rolled product, it can be stated that in the case of thicker products (above $9 \mathrm{~mm}$ ) the ratio of downgrading increases.
\end{abstract}

Keywords: steel, slab, coil, casting, quality.

\section{Összefoglalás}

Napjainkban egyre nagyobb kihívást jelent a minőségfejlesztés, mely nagy terhet ró a gazdaság szereplőire, főleg a kisebb vállalatokra. Az ISD Dunaferr Zrt. Magyarország legnagyobb acélipari létesítménye az éves kb. 2 millió tonna acéltermelésével, azonban világviszonylatban kicsinek számít. A lehetőségeket kihasználva, az esetleges rejtett problémák feltárásával komolyabb beruházás nélkül valósítható meg minőségi fejlesztés, illetve termelékenységnövelés. Jelen tanulmányban rámutatunk azon acélgyártási és -öntési paraméterekre, melyek szakmai szempontból a legnagyobb hatással bírnak a melegen hengerelt termék minőségére (tábla, és tekercs), valamint érintőlegesen vizsgáljuk a hengerelt termék alakítási mértékének hatását a leminősülési arányra. A hengerelt termékek vastagságával kapcsolatosan megállapítható, hogy a vastagabb termékek (9 mm felett) megnövekszik a leminősülés aránya

Kulcsszavak: acél, bramma, tekercs, öntés, minőség.

\section{Bevezetés}

A 2018 szeptemberében a Dunaferr Zrt. I. számú folyamatos öntőműve teljes rekonstrukción esett át, melynek legjelentősebb lépése a kristályosítói szint szabályzásautomatikájának a cseréje, modernizálása volt.
A rekonstrukció előtti és utáni időszak során gyártott brammákból készült, melegen hengerelt termékek leminősülési eredményeiből egyértelműen látszott a javulás.

A rekonstrukció után képződött adatok (3928 adag 16697 tekercse) további elemzése során 
megvizsgáltuk a különböző, elsősorban acél- és öntőműi gyártási paraméter kapcsolatát a melegen hengerelt termék leminősülési adataival.

Az ISD Dunaferr Zrt. Acélműve két LD-konverterrel (egyenként 135 tonnás kapacitással), valamint két vertikális elrendezésű folyamatos acélöntőművel (2-2 öntött szál) rendelkezik. A nyersacél kezelését a konverterek és az öntőgépek között elhelyezkedő, hevítési lehetőség nélküli háromállásos üstmetallurgiai állomás látja el. A konvertereket kettő, együttesen $\sim 4000 \mathrm{~m}^{3}$-es nagyolvasztó látja el nyersvassal.

Az oxigénes fuvatás után (LD-konverterben) a folyékony acél folyamatosan hül, míg meg nem szilárdul az öntőgépben. A hevítési lehetőség nélkül a kezelések mértéke korlátozott a konverter és a kristályosító között. A hűlés mértékét több körülmény befolyásolja. Például az ötvözők menynyisége, minősége és fajtája, az öblítő inert gáz mennyisége, de elsősorban az üst hőállapota.

\section{A konverter és az üstmetallurgiai állomás}

Az acélolvadékban fontos, hogy minimalizáljuk a zárványtartalmat, ennek megvalósítása az aktív oxigén diffúziós folyamatainak elősegítésével (pl. utánöblítés a konverterben), megfelelő mennyiségű és minőségű dezoxidálószer alkalmazásával, valamint a keletkezett zárványok minél nagyobb mértékű eltávolításával (inert gázos öblítés) érhetjük el.

Az oxigénes fúvatás után az acél aktívoxigén-tartalma elérheti a 800-1000 ppm koncentrációt is.

A vizsgálat során az alábbi technológiai tulajdonságokat elemeztük:

- Az inert gázos (argon) utánöblítés mennyisége a konverterben.

- Dezoxidálás céljából adagolt alumínium menynyisége fajtára lebontva (tömör „mokka”, laza „shredder”) [1].

- A végső alumíniumtartalom beállításához használt Al-huzal mennyisége az üstmetallurgiai állomáson.

- Az üstben lévő acél öblítésére felhasznált inert gáz (argon) mennyisége, amely forrás szerint lehet:

- az üstfenéken elhelyezett porózus téglán, „argonkövön” keresztül adagolt, ún. alsó argon;

- felülről, a felszín alá kb. 2 m-rel, lándzsán keresztül adagolt, nagy intenzitású, ún. felső argon.

A hengerelt termék folyékony fázisból „örökölt” tulajdonságai elsősorban a homogenitástól, a zár- ványtartalomtól és a kémiai összetételtől függenek. Ezen változók hatása főként a mechanikai tulajdonságokban (pl. szakítószilárdság, nyúlás) mutatkozik meg. Amennyiben a mechanikai tulajdonságok nem felelnek meg az acélminőség elvárásainak, többnyire átminősítik az adagot, és így nem képződik belőlük leminősülési esemény. Ezen okból a konverter és üstmetallurgiai állomás adatai nem mutattak összefüggést a leminősülési adatokkal.

A folyékony acél zárványtartalmából kifolyólag kizárólag akkor képződik leminősülési esemény, ha egy beavatkozás környékén kivett minta zárványmennyisége vagy -morfológiája indokolttá teszi, vagy ha a zárványok a hengerelt termék felszínén megjelennek, és ezáltal a gépi felületelemző rendszer (Cognex), illetve az emberi szem számára láthatóvá válik.

\section{A folyamatos acélöntőmü}

Az öntőgépi, azon belül is a kristályosítói folyamatok kapják a legnagyobb szerepet az öntött bramma külső és belső szerkezetének kialakulásában [2-4]. Az adatok vizsgálata rámutat arra, hogy a leminősülések jellemzően felületi repedés és felületi pikkely miatt történnek. E hibák kialakulása elsősorban a kristályosítóban lezajlódó komplex folyamatok következménye [5-7].

1. táblázat. A leminősülési okok megoszlása

\begin{tabular}{|l|l|}
\hline \multicolumn{1}{|c|}{ Leminősülési ok } & Arány \\
\hline Szakadt szél & $0,00 \%$ \\
\hline Szélpikkely & $0,20 \%$ \\
\hline Szélrepedés & $0,05 \%$ \\
\hline Felületi pikkely & $1,18 \%$ \\
\hline Felszakadás & $0,11 \%$ \\
\hline Felületi zárvány & $0,27 \%$ \\
\hline Felületi repedés & $0,14 \%$ \\
\hline Zárványvizsgálat alapján & $0,18 \%$ \\
\hline Összes leminősülés & $\mathbf{2 , 1 1 \%}$ \\
\hline
\end{tabular}

\subsection{Közbenső üst}

A közbenső üst szerepe elsősorban a pufferképzés, ami elengedhetetlen a folyamatos öntés biztosítására az acélüstök cseréje során. A közbenső üstben elhelyezett hőmérsékletmérő szonda szolgáltat adatot a kristályosítóba kerülő acél hőfokáról. Az acél összetételéből számított likvidusz hőfok és a mért tényleges hőfok különbsége megadja a folyékony acél túlhevítettségének mértékét. A kismértékű túlhevítettség technológiai kockáza- 
tot jelent, mert az öntött acél idő előtt elfagyhat, és nincs lehetőség a konverteren kívül hőközlésre. A nagymértékű túlhevítettség öntési biztonságot jelent, azonban nagyobb terhet visz a hütési rendszerre (kristályosító, másodlagos hütés).

Az acél hủlése során eltolódó Al-O egyensúly finom zárványkiválást indít el, ami annál jelentősebb, minél nagyobb mértékű a hűlés. A kristályosítóban az intenzív, direkt hőelvonás hatására ez a jelenség felerősödik, és könnyebben kerülhet zárvány a felszín közelébe.

Az 1. ábrán megfigyelhető a túlhevítés mértékének hatása a leminősülésekre.

\subsection{A kristályosító}

A kristályosító oszcilláló mozgást végezve [810] szilárd kérget képez a folyékony acélon, mely képes az alsó zónákba történő haladása során a ferrosztatikus nyomás ellenében a belső folyékony részt megtartani. A kristályosítóban a hő elvezetése vízhűtéses, nikkelbevonatú rézlapokon keresztül történik.

\subsubsection{A kristályosító életkora}

A kristályosítót az öntés során több mechanikai hatás éri, melyek egyenetlen kopásokat, bemaródásokat okozhatnak a kristályosító belső felületén, és ezek a belső egyenetlenségek kihathatnak a bramma felületi minőségére. Az indítószál alulról történő beadása miatt a hütőlapok alsó részén mechanikai kopás lép fel. A folyékony acél fröccsenésekor az acélcseppek belehegedhetnek a hűtőlapok felületébe; ezeket az egyenetlenségeket hideg állapotban csiszolással távolítják el. A tartott acélszint meniszkuszánál a folyékony

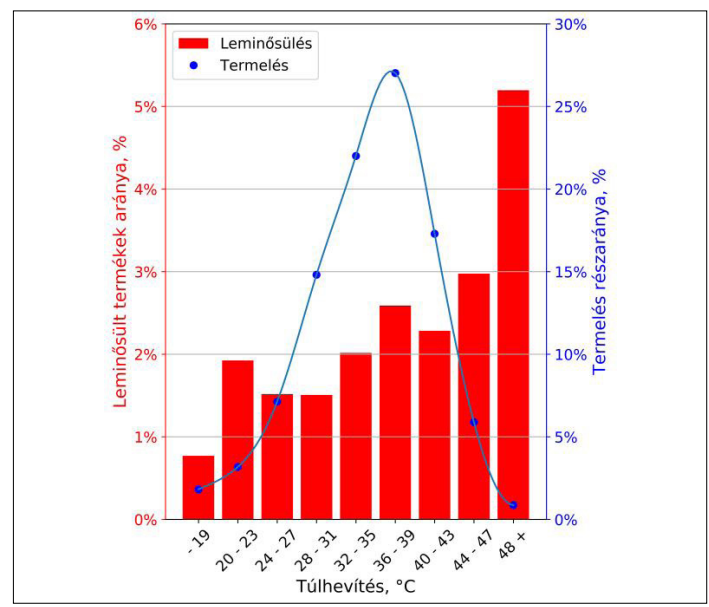

1. ábra. Leminösülések kapcsolata a túlhevítettség mértékével acél, valamint a beolvadó öntőpor nyomai figyelhetők meg.

$\mathrm{Az}$ értékek a feltételezéssel ellentétben a 2. ábrán nem mutatnak szignifikáns összefüggést a leminősülés mértéke és a kristályosító életkora között. Feltételezhetően azért, mert a szilárd és folyékony acél csak a rövid szakaszon érintkezik közvetlenül a kristályosító falával, és ezen a szakaszon nem tud olyan mély egyenetlenség kialakulni, melynek a mélysége meghaladná később, a hevítőkemencében leégő réteg vastagságát.

\subsubsection{Az öntési sebesség és kristályosítói olva- dékszint ingadozása}

Az öntési sebesség, valamint a kristályosító acélfelszínének változása jelentős hatást fejt ki az öntött szálnak mind a belső, mind a külső tulajdonságaira [11-15]. E változások idő- és hosszváltozás szerinti vizsgálata nem hozott számottevő eredményt, ami feltételezhetőleg annak köszönhető, hogy a jelentősebb változással terhelt szálszakaszokat kivágják és a későbbiekben nem használják fel, ezáltal nem is okozhatnak számottevő leminősülést.

\subsection{A másodlagos hütőzóna}

A kristályosító alatt elhelyezkedő másodlagos hütési zónák szerepe egyrészt az öntött szál egytengelyü, stabil megtámasztása, valamint a szál további hűtése és teljes keresztmetszetű megszilárdítása. Korábbi megfigyelések alapján az öntés során előforduló megtámasztási problémák (pl. csapágytörés, a görgők felületi kipattogzása) gyorsan és szembetűnően jelentkeznek. Ezek a vizsgált időszakban nem léptek fel, ezért hatásuk

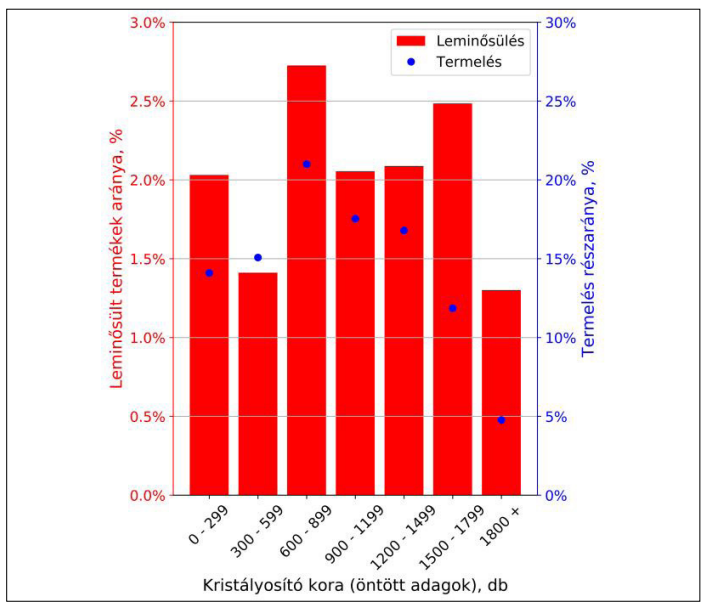

2. ábra. Leminösülések kapcsolata a kristályositó életkorával 
vizsgálata nem történt meg.

Az öntött szál hűtési stratégiáját elsősorban az acélminőség, illetve a szálszélesség (szelvényméret) határozza meg. A túlhevítettség mértéke a szál maximális húzási sebességére van hatással, úgy, hogy a megfelelő hőelvonás meg tudjon valósulni a teljes keresztmetszet megszilárdulásának érdekében.

A vizsgált acélminőségek hütési stratégiájára a kémiai hasonlóság miatt csak a szelvényméret gyakorol hatást, ezért ez alapján történt a vizsgálat.

A 3. ábra adataiból szembetűnő a legszélesebb szelvénynél tapasztalható kiugró leminősülési arány.

A B15 szelvényen öntött jelentős mennyiség, valamint a rendszeres ellenőrzés mellett jelentkező nagymértékű leminősülés kizárja, hogy a helyi fúvókák hibájából, esetleges eltömődéséből adódna a probléma. Inkább arra enged következtetni, hogy a gyártási sorban (öntőmű, meleghengermű) a szelvénymérettől függő technológiai jellemző(k) miatt alakul ki a jelenség. A pontos okok feltárása túlmutat jelen vizsgálaton.

\section{A meleghengerlés}

Jelen vizsgálatban elsősorban az acélműi technológiai változókat elemeztük. A meleghengerműi gyártási jellemzők nem képezték a vizsgálat tárgyát, azonban tapasztalatok alapján célszerünek látszott a hengerelt termék vastagságának (az alakítás mértékének) és a leminősülés összefüggésének vizsgálata. A vizsgált vastagságkategóriák kiválasztása a járatos termékek gyártástechnológiájának megfelelően történt.

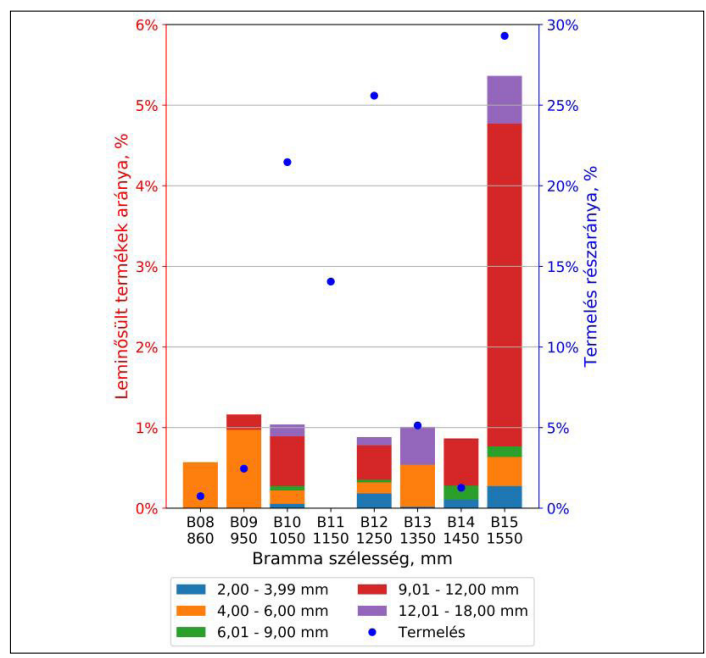

3. ábra. Leminősülések kapcsolata a szelvénymérettel
A sejtésnek megfelelően a 4. ábra alapján is látható, hogy a vastagabb termékek esetén jelentősen megugrik a leminősülés mértéke.

\section{Következtetések}

A konverter és az üstmetallurgiai állomás vizsgált jellemzői elsősorban a melegen hengerelt termék mechanikai tulajdonságaira gyakorolnak hatást. Nem megfelelőség esetén a terméket átsorolják más minőségre. Feltehetően ezen okból a vizsgálatok nem mutattak összefüggést a leminősüléssel.

A túlhevítések mértékének vizsgálatánál összefüggés figyelhető meg a leminősülési adatokkal. Kismértékű túlhevítettség esetén az öntési láncban fellépő hủlés miatt már megindulhat az acél megszilárdulási folyamata. A nagymértékű túlhevítettség esetén viszont növekszik a kristályosító hőterhelése, ami a továbbiakban a szál felületére gyakorol negatív hatást. A jelenlegi, többségében 35-40 ํ-os túlhevítettséggel történő öntés a nem állandó beszállítói forrásból történő alapanyagés tűzállóanyag-ellátás következménye. A bizonytalanság miatt folyamatosan biztonsági hőtartalék tartása szükséges. Folyamatos, állandó forrásból származó alapanyaggal és tűzálló anyaggal csökkenthető a csapolási és öntési hőmérséklet, ami minőségjavuláshoz és költségmegtakarításhoz vezet.

A kristályosító életkora és a leminősülések vizsgálata nem mutatott összefüggést. Ez feltehetőleg a rövid ideig tartó, közvetlen acélolvadék-kristályosítófal-érintkezés következménye, amely során nem tud kialakulni olyan mélységü, a kristá-

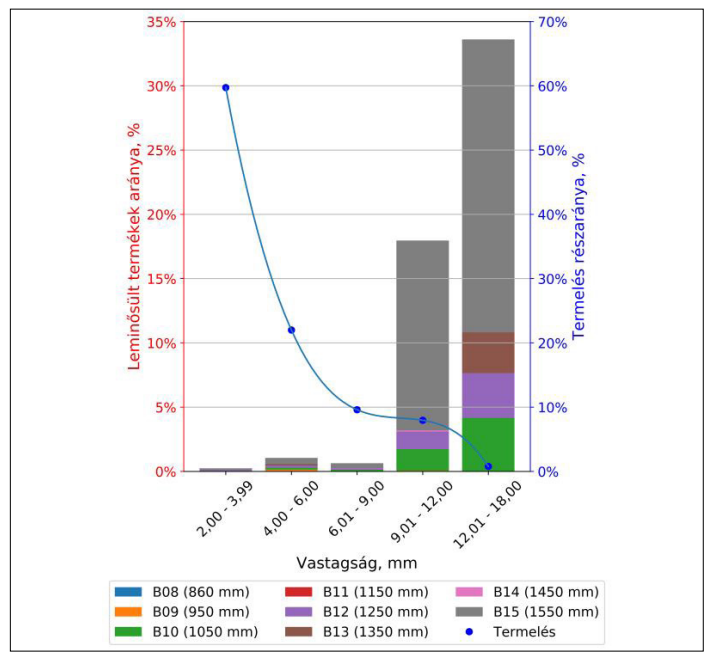

4. ábra. Leminösülések kapcsolata a hengerelt termék vastagságával 
lyosító egyenetlen felületéből adódó hiba, mely a hevítőkemencében nem égne le.

Az öntési sebesség és kristályosítói acélszint változásának vizsgálata nem hozott értékelhető eredményt. Ez elsősorban feltételezhetően annak köszönhető, hogy a jelentősebb változással érintett szálszakaszokat kivágják, és nem kerül sor a hengerlésükre.

Az 1550 mm széles (B15) szelvényméretnél tapasztalható, a többihez képest jelentősen nagyobb leminősülési arányt az adatok alapján nem karbantartási probléma (pl. fúvókaeltömődés), hanem más, szelvényméretfüggő, valószínűleg hűtési sajátosság okozza. A hiba okának feltárása komplexen érinti mind az öntőmű, mind a meleghengermű hütési stratégiájának felülvizsgálatát.

A termék hengerelt vastagságát vizsgálva látható a szelvénymérettől függetlenül is, hogy a vastagabb termékek esetén ( $9 \mathrm{~mm}$ felett) nagyságrendileg megugrik a leminősülés mértéke. Ez az ugrás a $12 \mathrm{~mm}$-nél vastagabb anyagok esetén részben magyarázható azzal, hogy kizárólag tekercsben értékesíthető, mert nincs lehetőség darabolásra, és így részleges hiba esetén is teljes tekercset kell leminősíteni. A 3. és 4. ábra alapján látható, hogy a vastag termékeket (9 mm felett) nagyobbrészt a B15-ös szelvényen gyártják.

A fenti adatok alapján kijelenthető, hogy a bramma szélességéből és a hengerelt termék vastagságából adódó hatások összeadódnak, és jelentősen megnövelik a leminősülés veszélyét a vastag, széles termékeknél.

\section{Köszönetnyilvánítás}

EFOP-3.6.1-16-2016-00003 K+F+I folyamatok hosszú távú megerősítése a Dunaújvárosi Egyetemen projekt által finanszírozott kutatás.

\section{Szakirodalmi hivatkozások}

[1] Wizner K., Kővári A.: Efficiency of different kinds of aluminiums during deoxidation in the Steelworks of ISD Dunaferr Co. Ltd. IOP Conf. Series: Materials Science and Engineering, 426. (2018) 012052 https://doi.org/10.1088/1757-899X/426/1/012052

[2] Meng Y., Thomas B. G.: Heat transfer and solidifcation model of continuous slab casting: CON1D. Metall. \& Material Trans., 34B/5. (2003) 685-705. https://doi.org/10.1007/s11663-003-0040-y

[3] Zhang L., Pluschkell W., Thomas B. G.: Nucleation and growth of alumina inclusion during steel deoxidation. In: Proceeding of $85^{\text {th }}$ Steelmaking Conference, Vol. 85. ISS, Warrendale, PA, 2002. 463-476.
[4] Thomas B. G., Jenkins M., Mahapatra R. B.: Investigation of strand surface defects using mold instrumentation and modeling. Ironmaking \& Steelmaking, 31/6. (2004) 485-494.

https://doi.org/10.1179/030192304225019261

[5] Brimacombe J. K., Sorimachi K.: Crack formation in the continuous casting of steel. Metallurgical Transactions, B, 8/2. (1977) 489-505. https://doi.org/10.1007/BF02696937

[6] Schmidt K.-D. et al.: Consequent improvement of surface quality by systematic analysis of slabs. Steel Research, 74/11. (2003) 659-666.

[7] Thomas B. G.: Modeling of continuous casting defects related to mold fluid flow. In: Proceeding of $3^{\text {rd }}$ Int. Congress on Science \& Technology of Steelmaking, AIST, Warrendale, PA, 2005. 847-861.

[8] Shin H.-J., Lee G. G., Choi W. Y., Kang S. M., Park J. H., Kim S. H., Thomas B.G.: Effect of mold oscillation on powder consumption and hook formation in ultra low carbon steel slabs. Iron Steel Technology, 2/9. (2004) 15-17.

[9] Thomas B. G., Sengupta J., Ojeda C.: Mechanism of hook and oscillation mark formation in ultra-low carbon steel. In: Proceeding of Second Baosteel Biennial Conference, Vol. 1, 2006. 112-117.

[10] Sengupta J., Thomas B. G., Shin H.-J., Lee G. G., Kim S.-H.: A new mechanism of hook formation during continuous casting of ultra-low-carbon steel slabs. Metallurgical and Materials Transactions, 37/5. (2006) 1597-1611. https://doi.org/10.1007/s11661-006-0103-1

[11] Thomas B. G.: Continuous Casting of Steel. In: Modelling for casting and solidification process, (Szerk: O. Yu) Marcel Dekker, New York, NY, 2001. 499-540.

[12] Sengupta J.: Effect of a sudden level fluctuation on hook formation during continuous casting of ultralow carbon steel slabs. In: Modeling of Casting, Welding, and Advanced Solidification Processes XI. (Szerk. Gandin C. A., Allison J. E.). TMS, Warrendale, PA, 2006. 727-736.

[13] Shin H-J., Thomas B. G., Lee G. G., Park J. M., Lee C. H., Kim S. H.: Analysis of hook formation mechanism in ultralow-carbon steel using CON1D heat flow solidification model. Materials Science and Technology 2, TMS, Warrendale, PA, Vol. II, 2004. 11-26.

[14] Zhang Q., Wang L., Wang X.: Influence of casting speed variation during unsteady continuous casting on non-metallic inclusions in IF steel slabs. ISIJ International, 46/10. (2006) 1421-1426.

[15] Wang Y., Zhang L.: Transient fluid flow phenomena during continuous casting: Part II-cast speed change, temperature fluctuation, and steel grade mixing. ISIJ International, 50/12. (2010) 17831791.

https://doi.org/10.2355/isijinternational.50.1783 